\title{
PPARd activation protects H9c2 cardiomyoblasts from LPS-induced apoptosis through the heme oxygenase-1-mediated suppression of NF- $\mathrm{KB}$ activation
}

\author{
$\mathrm{YAO} \mathrm{SHI}^{1}$, HONG JIANG ${ }^{1}$ and XIAOBO YANG ${ }^{2}$ \\ ${ }^{1}$ Department of Neonatology, the Central Hospital of Wuhan, Tongji Medical College, \\ Huazhong University of Science and Technology, Wuhan, Hubei 430014; ${ }^{2}$ Department of Ophthalmology, Union Hospital, \\ Tongji Medical College, Huazhong University of Science and Technology, Wuhan, Hubei 430022, P.R. China
}

Received March 7, 2016; Accepted February 23, 2017

DOI: $10.3892 / \mathrm{mmr} .2017 .6483$

\begin{abstract}
The aim of the present study was to investigate the protective effect of the selective peroxisome proliferator-activated receptor $\delta$ (PPAR $\delta$ ) agonist GW501516 (GW) on lipopolysaccharide (LPS)-induced apoptosis in the rat cardiomyoblast cell line $\mathrm{H} 9 \mathrm{c} 2$, and to investigate the possible underlying mechanisms. Cell viability was estimated using the MTT assay. Apoptosis was estimated by flow cytometry using Annexin V-fluorescein isothiocyanate/propidium iodide staining and caspase-3 activity assay. The protein level of heme oxygenase-1 (HO-1), cleaved caspase-3 (CC3), apoptosis regulator $\mathrm{Bcl}-2$ (bcl-2), apoptosis regulator $\mathrm{BAX}$ (bax) and nuclear factor- $\mathrm{\kappa B}(\mathrm{NF}-\mathrm{\kappa B})$ p 65 was measured by western blot analysis. The results demonstrated that pretreatment with GW inhibited the LPS-induced increase in the rate of apoptosis. Pretreatment with GW also increased the bcl-2/bax ratio, and decreased $\mathrm{CC} 3$ protein expression as well as caspase-3 activity, in LPS-stimulated H9c2 cells. Further studies demonstrated that GW inhibited LPS-induced NF- $\kappa B$ nuclear translocation in a dose-dependent manner. In addition, GW induced HO-1 protein expression in a dose-dependent manner. ZnPP-IX, an inhibitor of HO-1, reversed the inhibitory effect of GW on LPS-induced NF- $\mathrm{\kappa B}$ activation, leading to the attenuation of PPAR $\delta$-mediated apoptosis resistance. In conclusion, these results suggest that PPAR $\delta$ activation exerts an anti-apoptotic effect in LPS-stimulated $\mathrm{H} 9 \mathrm{c} 2$ cardiomyoblasts, potentially through heme oxygenase-1-mediated suppression of NF- $\mathrm{KB}$
\end{abstract}

Correspondence to: Dr Xiaobo Yang, Department of Ophthalmology, Union Hospital, Tongji Medical College, Huazhong University of Science and Technology, 1277 Jiefang Road, Wuhan, Hubei 430022, P.R. China

E-mail: yangxb079@sina.com

Key words: peroxisome proliferator activated receptor $\delta$, cardiomyoblasts, apoptosis, lipopolysaccharide, heme oxygenase-1, nuclear factor- $\kappa \mathrm{B}$ activation. PPAR $\delta$ appears to be a promising therapeutic target for the treatment of sepsis-associated cardiac dysfunction.

\section{Introduction}

Sepsis remains a significant health problem among pediatric patients (1). Worldwide, it affects a large pediatric population and is the most common cause of mortality in infants and children (2): Accumulating evidence has indicated that myocardial dysfunction is a common complication in adults and children with severe sepsis (3). However, the cellular mechanisms underlying sepsis-associated myocardial dysfunction are not entirely clear. There is increasing evidence that apoptosis of cardiomyocytes serves an important role in the pathogenesis of sepsis-induced myocardial dysfunction (4). Therefore, therapeutic strategies aimed at preventing the sepsis-induced apoptosis of cardiomyocytes may be a promising option for the treatment of sepsis-associated myocardial dysfunction.

Peroxisome proliferator-activated receptors (PPARs) are ligand-activated nuclear transcriptional activators belonging to the superfamily of nuclear receptors. A total of three PPAR subtypes $(\alpha, \beta / \delta$ and $\gamma$ ) have been identified (5). Although the function of the ubiquitously-expressed PPAR $\delta$ subtype has received relatively little attention in comparison with the other two subtypes, it has been reported to exhibit a potent role in the regulation of cellular metabolism (6), inflammation (7), apoptosis (8) and angiogenesis (9). Previous experimental evidence has indicated that PPAR $\delta$ activation protects $\mathrm{H} 9 \mathrm{c} 2$ cells from oxidative stress-induced apoptosis (10). However, the possible anti-apoptotic effect of PPARS activation in lipopolysaccharide (LPS)-stimulated H9c2 cells has not been tested. Furthermore, the precise mechanism underlying this response remains unclear.

Molecular and pharmacological strategies that prevent nuclear factor- $\kappa \mathrm{B}(\mathrm{NF}-\kappa \mathrm{B})$ activation have been demonstrated to provide considerable myocardial protection in models of endotoxin challenge, thus confirming the vital role of this transcription factor in mediating sepsis-associated myocardial dysfunction (11). Heme oxygenase-1 (HO-1), which is the rate-limiting enzyme responsible for 
the degradation of heme into free ferrous iron, $\mathrm{CO}$ and bilirubin, exerts cytoprotective effects in various diseases (12). It is reported that HO-1 induction serves an important role in the cytoprotective actions of PPAR $\delta$ in vascular endothelia (13). Recent experimental evidence indicates that heme oxygenase-1 overexpression protects human cardiac endothelial cells from IL-18-induced apoptosis by inhibiting $\mathrm{NF}-\kappa \mathrm{B}$ activation (14). Therefore, the present study was designed to investigate the effect of the PPAR $\delta$-selective agonist GW501516 (GW) on LPS-induced apoptosis in the rat cardiomyoblast cell line $\mathrm{H} 9 \mathrm{c} 2$, and to analyze the role of $\mathrm{NF}-\mathrm{\kappa B}$ and $\mathrm{HO}-1$ in this effect.

\section{Materials and methods}

Materials. GW was obtained from Santa Cruz Biotechnology, Inc. (Dallas, TX, USA). Zinc protoporphyrin-IX (Znpp-IX, an HO-1 inhibitor), dimethyl sulfoxide (DMSO), trypsin and MTT were from Sigma-Aldrich (Merck KGaA, Darmstadt, Germany). All culture reagents were from Invitrogen (Thermo Fisher Scientific, Inc., Waltham, MA, USA). LPS, phenylmethanesulfonyl fluoride (PMSF), radioimmunoprecipitation assay (RIPA) buffer, the enhanced bicinchoninic acid (BCA) protein assay kit, all SDS-PAGE reagents, the nuclear and cytoplasmic protein extraction kit, the enhanced chemiluminescence (ECL) substrate reagent kit and the caspase-3 activity kit were obtained from Beyotime Institute of Biotechnology (Jiangsu, China). The Annexin V-fluorescein isothiocyanate (FITC)/propidium iodide (PI) detection kit was from KeyGen Biology (Nanjing, China). Rabbit polyclonal antibodies specific for cleaved caspase-3 (CC3; cat. no. 9661), apoptosis regulator Bcl-2 (bcl-2; cat. no. 2876), apoptosis regulator BAX (bax; cat. no. 2772), NF-кB p65 (cat. no. 3034) and anti-GAPDH (cat. no. 2118; 1:1,000) were from Cell Signaling Technology, Inc. (Danvers, MA, USA). Rabbit polyclonal antibodies specific for HO-1 (cat. no. SPA-896) and histone 3 (H3; cat. no. ab1791) were obtained from Stressgen Bioreagents Corporation (Victoria, BC, Canada) and Abcam (Cambridge, UK), respectively.

Cell culture and treatment protocol. $\mathrm{H} 9 \mathrm{c} 2$ cardiomyoblasts (CRL-1446; American Type Culture Collection, Manassas, VA, USA) were maintained in Dulbecco's modified Eagle's medium (DMEM) supplemented with $10 \%$ heat-inactivated fetal bovine serum (FBS), $100 \mathrm{U} / \mathrm{ml}$ penicillin and $100 \mu \mathrm{g} / \mathrm{ml}$ streptomycin in a humidified atmosphere of $5 \% \mathrm{CO}_{2}$ and $95 \%$ air at $37^{\circ} \mathrm{C}$. Cells were passaged regularly and subcultured to $90 \%$ confluence prior to experimental procedures.

GW dissolved in DMSO was diluted with low-serum medium (1\% FBS/DMEM) to the final concentrations $(25,50$ and $100 \mathrm{nmol} / \mathrm{l}$ ) before use. The final concentration of DMSO in the incubation mixture was not more than $0.1 \%(\mathrm{v} / \mathrm{v})$. Prior to experimental intervention, confluent cultured cells were serum-starved for $24 \mathrm{~h}$ in low-serum medium. Cells were pretreated with different doses of GW for 24 hat $37^{\circ} \mathrm{C}$, and then incubated with $1 \mu \mathrm{g} / \mathrm{ml}$ of LPS for $24 \mathrm{~h}$. For the inhibitor experiment, cells were pretreated with $100 \mathrm{nM}$ of GW for $24 \mathrm{~h}$ at $37^{\circ} \mathrm{C}$ in the absence or presence of $10 \mu \mathrm{mol} / 1$ of ZnPP-IX, which was added $1 \mathrm{~h}$ before GW, and then the cells were incubated for $24 \mathrm{~h}$ with $1 \mu \mathrm{g} / \mathrm{ml}$ LPS.
Cell viability assay. Cell viability was assessed by MTT assay. Following incubation with the test reagents, $5 \mathrm{mg} / \mathrm{ml}$ MTT was added to the culture media and the cells were incubated for an additional $4 \mathrm{~h}$. Subsequent to this incubation, the resulting formazan was solubilized by adding DMSO, and the optical density of the solubilized cell extract was measured at $490 \mathrm{~nm}$ using a microplate reader.

Evaluation of cell apoptosis by Annexin V-FITC/PI staining. Apoptosis was detected using an Annexin V-FITC/PI detection kit according to the manufacturer's protocol. The cells were digested with $0.25 \%$ trypsin, washed with ice-cold PBS and resuspended in binding buffer $\left(5 \times 10^{5} \mathrm{cells} / \mathrm{ml}\right)$. The cells were centrifuged at $1,000 \mathrm{xg}$ for $5 \mathrm{~min}$ at $4^{\circ} \mathrm{C}$. Subsequent to the supernatant being discarded, $500 \mu \mathrm{l}$ binding buffer, $5 \mu \mathrm{l}$ Annexin V-FITC and $5 \mu 1$ PI were added to the cell suspension. Following gentle mixing, the suspensions were incubated for $15 \mathrm{~min}$ at room temperature without light. The cells were analyzed by flow cytometry (BD LSRII; BD Biosciences, Franklin Lakes, NJ, USA). Data analysis was performed using CellQuest version 3.3 (BD Biosciences).

Caspase-3 activity assay. Caspase-3 activity was determined using a caspase- 3 activity kit, which detects the production of the chromophore p-nitroanilide following its cleavage from the peptide substrate DEVD-p-nitroanilide. According to the manufacturer's protocol, following washing with cold PBS, cells were lysed with lysis buffer $\left(100 \mu \mathrm{l} / 2 \times 10^{6}\right.$ cells $)$ for $15 \mathrm{~min}$ on ice. The mixture, composed of $10 \mu \mathrm{l}$ cell lysate, $80 \mu \mathrm{l}$ reaction buffer and $10 \mu 12 \mathrm{mmol} / \mathrm{l}$ caspase-3 substrate, was incubated in 96 -well plates at $37^{\circ} \mathrm{C}$ for $4 \mathrm{~h}$, and caspase-3 activity was quantified in the samples using a microplate reader at an absorbance of $405 \mathrm{~nm}$.

Western blot analysis. Cells from each group were washed twice with ice-cold PBS and lysed in RIPA buffer $(10 \mathrm{mmol} / \mathrm{l}$ Tris, $\mathrm{pH} 7.4 ; 150 \mathrm{mmol} / 1 \mathrm{NaCl} ; 1 \mathrm{mmol} / \mathrm{l} \mathrm{EDTA} ; 0.1 \%$ SDS; $1 \%$ Triton X-100; and $1 \%$ sodium deoxycholate) with protease inhibitors $(1 \mathrm{mmol} / 1 \mathrm{PMSF}, 1 \mu \mathrm{g} / \mathrm{ml}$ aprotinin, $1 \mu \mathrm{g} / \mathrm{ml}$ pepstatin, and $1 \mu \mathrm{g} / \mathrm{ml}$ leupeptin) at $4^{\circ} \mathrm{C}$. The lysate was centrifuged at $12,000 \mathrm{xg}$ at $4^{\circ} \mathrm{C}$ for $20 \mathrm{~min}$ to remove the insoluble material. Supernatants were collected. The protein concentration was determined using the BCA assay. Equal quantities of protein $(30 \mu \mathrm{g})$ were separated by $10 \%$ SDS-PAGE, and subsequently transferred onto a polyvinylidene difluoride (PVDF) membrane. The membranes were blocked in TBS with Tween-20 (TBST) with 5\% (w/v) skimmed milk at room temperature for $2 \mathrm{~h}$, followed by overnight incubation at $4^{\circ} \mathrm{C}$ with primary antibodies diluted in $0.1 \%$ TBST. Following washing in TBST, the membranes were incubated at room temperature for $1 \mathrm{~h}$ with goat anti-rabbit horseradish peroxidase-conjugated secondary antibody (cat. no. 7074; 1:3,000; Cell Signaling Technology, Inc.) diluted in $0.1 \%$ TBST. Following washing once more in TBST, the immunoreactive bands were visualized by using an ECL kit and exposed to X-ray film. The band intensity was quantified using Quantity One software (Bio-Rad Laboratories Inc. Hercules, CA, USA).

Nuclear protein extraction. The extraction and isolation of nuclear proteins was performed using the nuclear and 
cytoplasmic protein extraction kit according to the manufacturer's protocol. Cells were detached with cold PBS and centrifuged at $1,000 \mathrm{x}$ for $5 \mathrm{~min}$ at $4^{\circ} \mathrm{C}$, and the pellet was dissolved with cytoplasmic protein extraction agent A supplemented with PMSF. Subsequent to mixing by vortex for $5 \mathrm{sec}$, the tubes were incubated for 10-15 min on ice to promote lysis. Cytoplasmic protein extraction agent $\mathrm{B}$ was added and mixing by vortex was performed for $5 \mathrm{sec}$, followed by incubation on ice for $60 \mathrm{sec}$. The samples were centrifuged for $5 \mathrm{~min}$ at $14,000 \mathrm{x}$ g at $4^{\circ} \mathrm{C}$ and the supernatant, consisting of the cytosolic fraction, was immediately frozen for further analysis. The pellet was re-suspended in nuclear protein extraction agent supplemented with PMSF. Subsequently, the tubes were mixed by vortex 15-20 times over the course of $30 \mathrm{~min}$ and centrifuged for $10 \mathrm{~min}$ at $14,000 \mathrm{x} \mathrm{g}$ at $4^{\circ} \mathrm{C}$ to obtain supernatants containing the nuclear extracts. Protein concentration was measured using the BCA protein assay kit. Levels of $\mathrm{NF}-\kappa \mathrm{B}$ p65 in the nuclear protein extract were determined by western blot analysis as described above.

Statistical analysis. All data represent the mean of samples from three separately-performed experiments. Results are expressed as mean \pm standard deviation. One-way analysis of variance and Student-Newman-Keuls tests were used for statistical evaluation with SPSS 14.0 software (SPSS, Inc., Chicago, IL, USA). P<0.05 was considered to indicate a statistically significant difference.

\section{Results}

$G W$ attenuates LPS-induced cytotoxicity. Using the MTT assay, a possible cytoprotective effect of GW against LPS-induced cell death was detected. To evaluate whether GW was cytotoxic to $\mathrm{H} 9 \mathrm{c} 2$ cells, the cells were first treated with concentrations of GW ranging between 25 and $100 \mathrm{nmol} / \mathrm{l}$ for 24 h. A reduction in cell viability was not observed (Fig. 1A). Subsequent analyses tested whether GW was able to protect against LPS-induced cytotoxicity. When cells were pretreated for $24 \mathrm{~h}$ with growing concentrations of GW (25-100 $\mathrm{nmol} / \mathrm{l})$, prior to treatment with $1 \mu \mathrm{g} / \mathrm{ml}$ LPS for $24 \mathrm{~h}$, significant increases in cell viability were observed compared with treatment with LPS alone. As exhibited in Fig. 1B, pretreatment with 50 and $100 \mathrm{nmol} / \mathrm{l} \mathrm{GW}$ significantly increased cell viability to $70.89 \pm 5.61$ and $81.16 \pm 7.12 \%$ of the control, respectively, compared with treatment with LPS alone. These results indicate that $\mathrm{GW}$ may have a protective role against LPS-induced cell cytotoxicity.

GW inhibits LPS-induced cell apoptosis. Apoptosis was quantitated by flow cytometry using Annexin V-FITC/PI staining. As presented in Fig. 2, LPS led to a significant increase in the apoptotic rate of $\mathrm{H} 9 \mathrm{c} 2$ cells compared with the control group, and the apoptotic rate was decreased markedly by pretreatment with GW compared with the LPS alone group. Subsequent western blot analysis demonstrated that CC3 protein expression was markedly increased in LPS-stimulated cells compared with the control group, while GW pretreatment decreased CC3 protein expression in a dose-dependent manner compared with the LPS group (Fig. 3). Western blot analysis also indicated that GW notably inhibited the decrease of the
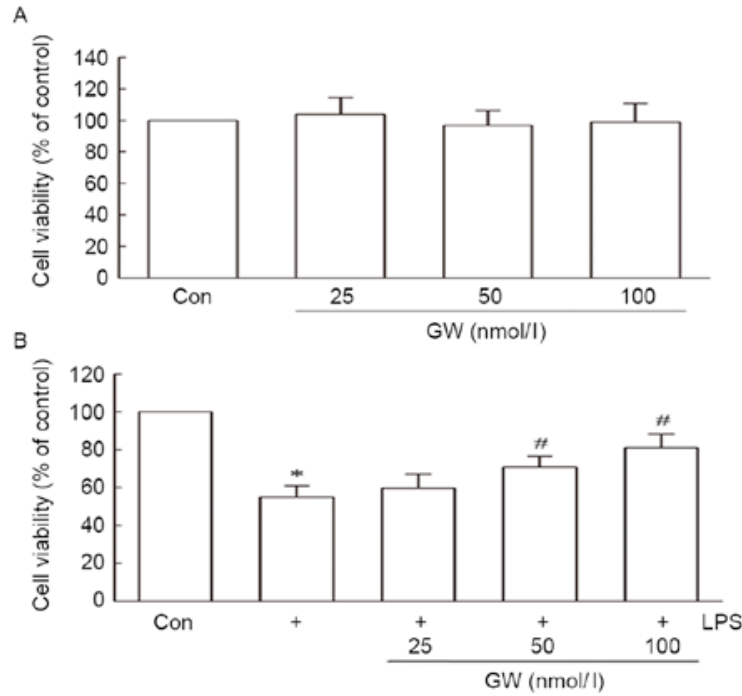

Figure 1. GW attenuates LPS-induced cytotoxicity in a dose-dependent manner. (A) Effect of GW on cell viability detected by MTT assay. (B) GW protects the cells from LPS-induced cytotoxicity in a dose dependent manner. Data are presented as mean \pm standard deviation $(n=3)$. ${ }^{*} \mathrm{P}<0.05$ vs. Con; ${ }^{\#} \mathrm{P}<0.05$ vs. LPS. Con, control; GW, GW501516; LPS, lipopolysaccharide.

bcl-2/bax ratio induced by LPS in a dose-dependent manner (Fig. 4).

$G W$ inhibits LPS-induced $N F-\kappa B$ nuclear translocation. To investigate the molecular mechanisms by which $\mathrm{GW}$ protects $\mathrm{H} 9 \mathrm{c} 2$ cells from LPS-induced apoptosis, the nuclear $\mathrm{NF}-\kappa \mathrm{B}$ protein expression level was examined to determine whether the regulation of $\mathrm{NF}-\kappa \mathrm{B}$ is responsible for the anti-apoptotic effect of GW. As displayed in Fig. 5, when cells were pretreated for $24 \mathrm{~h}$ with increasing concentrations of GW prior to incubation with LPS, NF- $\kappa \mathrm{B}$ protein expression was decreased in a dose-dependent manner compared with the LPS group. These results suggest that GW prevents LPS-induced apoptosis, possibly through inhibition of $\mathrm{NF}-\kappa \mathrm{B}$ activation.

GW induces $\mathrm{HO}-1$ protein expression. The cells were treated with increasing concentrations of GW (25-100 nmol/l). Treatment with GW for $24 \mathrm{~h}$ increased HO-1 expression in a dose-dependent manner (Fig. 6A). HO-1 expression was subsequently determined by treating the cells with $100 \mathrm{nmol} / \mathrm{l}$ GW for 12, 24 and 48 h. As presented in Fig. 6B, a maximum increase of HO-1 protein expression was observed following treatment for $24 \mathrm{~h}$.

HO-1 mediates the protective effect of $G W$ against $L P S$-induced cell apoptosis. In order to validate the protective role of HO-1, H9c2 cells exposed to LPS were pretreated with $100 \mathrm{nmol} / 1 \mathrm{GW}$ for $24 \mathrm{~h}$ in the absence or the presence of $10 \mu \mathrm{M}$ ZnPP-IX. As exhibited in Fig. 7, the caspase-3 activity was increased by $9.42 \pm 0.61$-fold that of the control in the LPS group, whereas it was reduced to $3.07 \pm 0.24$-fold that of the control following pretreatment with GW. Co-incubation with $\mathrm{ZnPP}-\mathrm{IX}$, which partly negated the effect of $\mathrm{GW}$, increased the caspase-3 activity to $6.91 \pm 0.40$-fold that of the control. These results suggest that the protective effect of GW on LPS-induced cell apoptosis is HO-1-dependent. 

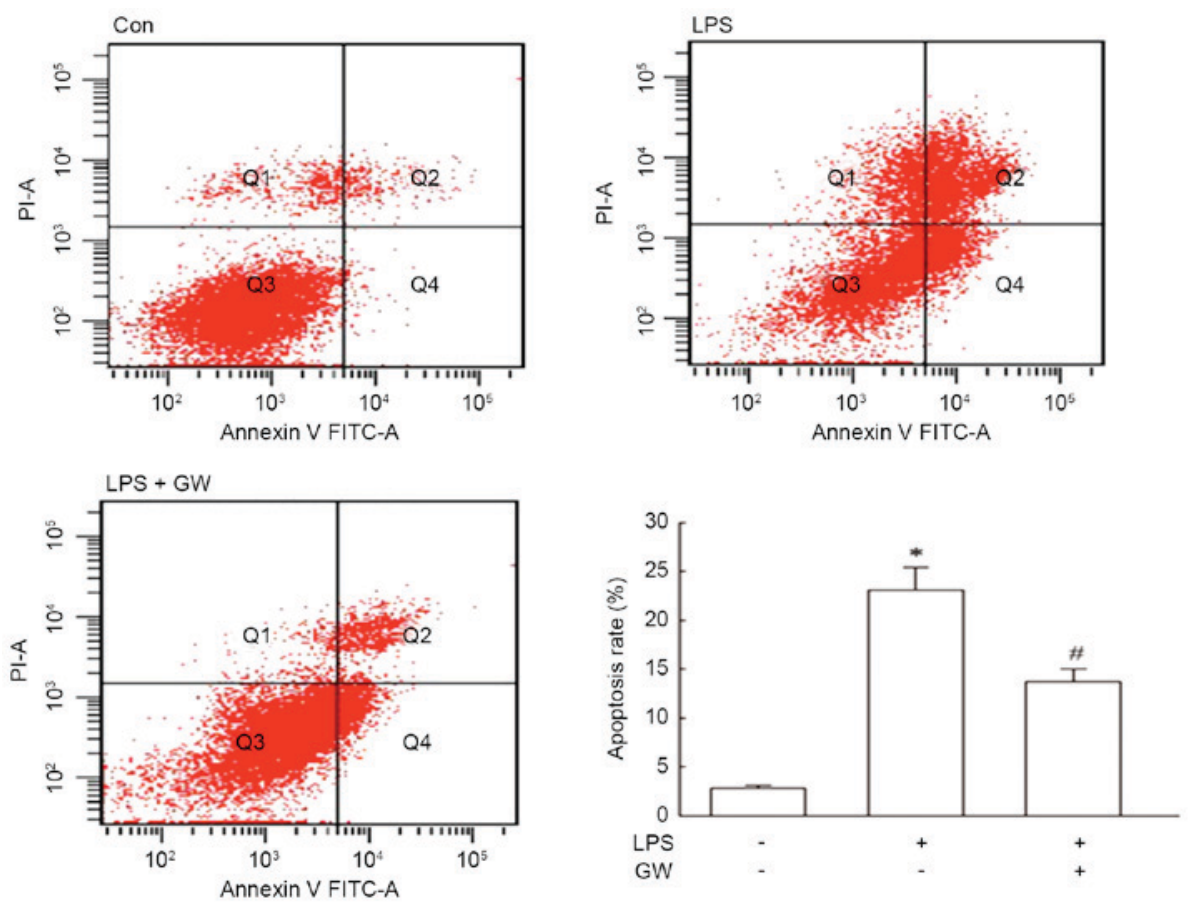

Figure 2. GW inhibits LPS-induced apoptosis. Cells were pretreated with $100 \mathrm{nmol} / \mathrm{l} \mathrm{GW}$ for $24 \mathrm{~h}$ and then incubated with $1 \mu \mathrm{g} / \mathrm{ml} \mathrm{LPS}$ for $24 \mathrm{~h}$. The percentage of apoptotic cells (Annexin V+/PI-) was calculated. Data are presented as mean \pm standard deviation ( $\mathrm{n}=3$ ). ${ }^{*} \mathrm{P}<0.05$ vs. control; " $\mathrm{P}<0.05$ vs. LPS GW, GW501516; FITC, fluorescein isothiocyanate; LPS, lipopolysaccharide; PI, propidium iodide.

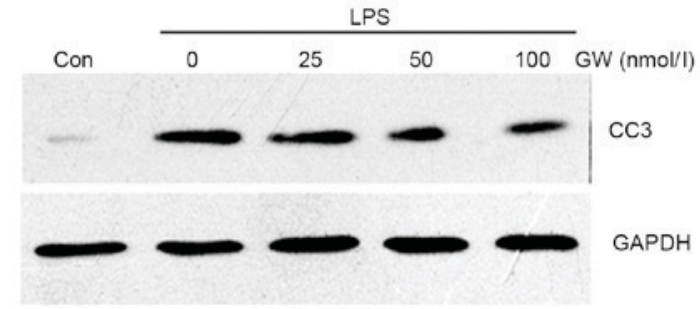

Figure 3. GW inhibits LPS-induced increase of CC3 protein expression in a dose-dependent manner. Cells were pretreated GW for $24 \mathrm{~h}$ and incubated with $1 \mu \mathrm{g} / \mathrm{ml}$ LPS for $24 \mathrm{~h}$. CC3 expression was determined using western blot analysis. CC3, cleaved caspase 3; GW, GW501516; LPS, lipopolysaccharide; Con, control.

HO-1 mediates the inhibitory effect of $G W$ on $N F-\kappa B$ activation. To determine whether the upregulation of HO-1 by GW is important to the survival of $\mathrm{H} 9 \mathrm{c} 2$ cells, due to the modulation of NF- $\kappa \mathrm{B}$, the effects of ZnPP-IX on the expression of NF- $\mathrm{BB}$ were tested. H9c2 cells exposed to LPS were pretreated with $100 \mathrm{nmol} / \mathrm{l} \mathrm{GW}$ for $24 \mathrm{~h}$ in the absence or the presence of $10 \mu \mathrm{M} Z n P P-I X$. As presented in Fig. 8,ZnPP-IX co-incubation reversed the inhibitory effect of GW on LPS-induced NF- $\mathrm{kB}$ activation, suggesting that HO-1 may mediate the inhibitory effect of GW on NF- $\mathrm{KB}$ activation in LPS-stimulated H9c2 cells.

\section{Discussion}

The present study investigated the anti-apoptotic effect elicited by the selective PPARס agonist GW in LPS-stimulated H9c2 cardiomyoblasts. The possible mechanism underlying this anti-apoptotic effect was also investigated. It was demonstrated that the activation of NF- $\mathrm{KB}$, induced by LPS, was inhibited

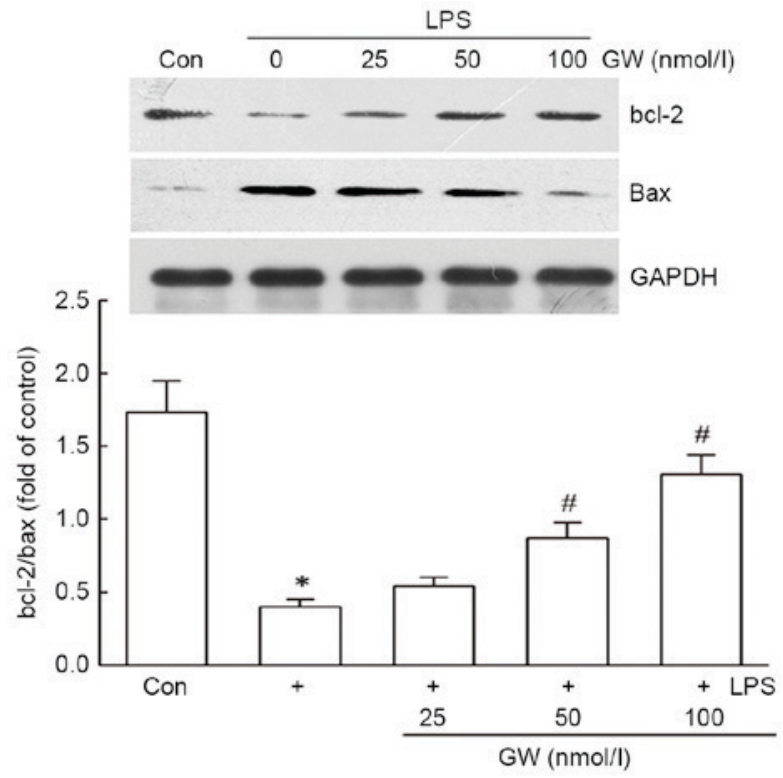

Figure 4. GW increases the bcl-2/bax ratio in a dose-dependent manner. Cells were pretreated with GW for $24 \mathrm{~h}$ followed by incubation with LPS for additional $24 \mathrm{~h}$ and bcl-2 and bax were determined using western blot. Data are presented as mean \pm standard deviation $(\mathrm{n}=3)$. ${ }^{\text {}} \mathrm{P}<0.05$ vs. Con; ${ }^{~} \mathrm{P}<0.05$ vs. LPS. bcl-2, apoptosis regulator $\mathrm{Bcl}-2$; bax, apoptosis regulator BAX; Con, control; GW, GW501516; LPS, lipopolysaccharide.

significantly by pretreatment with GW. GW also induced HO-1 protein expression in a dose-dependent manner. In addition, it was revealed that HO-1 mediated the inhibitory effect of GW on NF- $\mathrm{kB}$ activation in LPS-stimulated H9c2 cells.

The protective effect of GW against LPS-induced cell toxicity was investigated by MTT assay. The results demonstrated that GW protected H9c2 cells from LPS-induced 


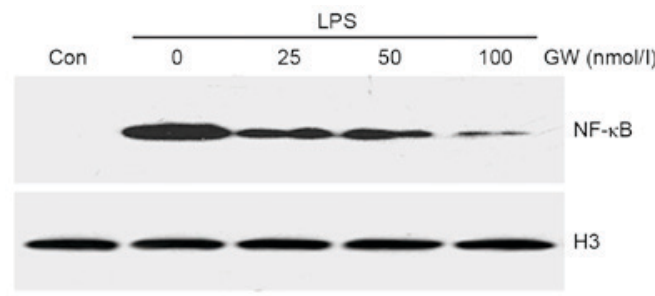

Figure 5. GW inhibits LPS-induced NF- $\mathrm{kB}$ nuclear translocation in a dose-dependent manner. Cells were treated with GW and LPS, NF-kB was determined using western blot analysis. Con, control; GW, GW501516; LPS,

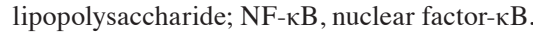

A

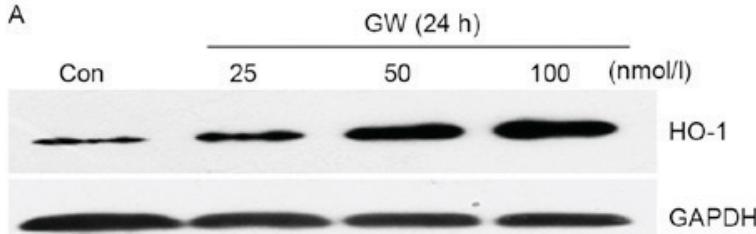

B

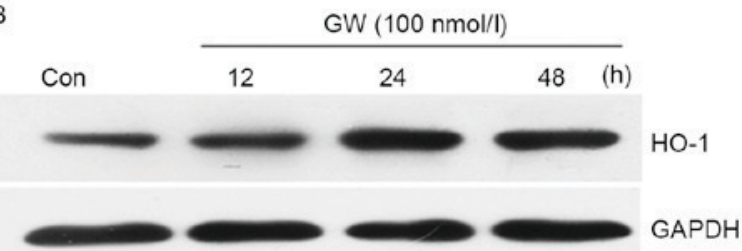

Figure 6. GW induces $\mathrm{HO}-1$ protein expression in a dose-dependent manner (A) Cells were treated with 25, 50, $100 \mathrm{nmol} / \mathrm{l} \mathrm{GW}$ alone for $24 \mathrm{~h}$. (B) Cells were treated with $100 \mathrm{nmol} / \mathrm{l} \mathrm{GW}$ alone for 12,24 and $48 \mathrm{~h}$. HO-1 was determined by western blot analysis. Con, control; GW, GW501516; HO-1, heme oxygenase-1.

cytotoxicity in a dose-dependent manner. It is known that LPS is a major feature of Gram-negative septic shock, and it has been tested as a stress model for inducing apoptosis in vitro (15). Previously, the activation of PPARS was demonstrated to be implicated in the suppression of apoptosis in human umbilical vein endothelial cells (16). Therefore, the present study examined whether GW has a protective effect against LPS-induced apoptosis in H9c2 cells.

Apoptosis is typically associated with the regulation of caspase-3 (17) and the family of bcl-2 proteins which include pro-apoptotic protein bax and anti-apoptotic protein bcl-2 (18). The present study provided evidence that pretreatment with GW significantly inhibited the LPS-induced increase in the rate of apoptosis as measured by Annexin V-FITC/PI staining. It was also observed that GW may significantly decrease the expression of $\mathrm{CC} 3$, and caspase-3 activity, which are accompanied by a marked increase in the bcl-2/bax ratio. These results demonstrated that the activation of PPAR $\delta$ may protect $\mathrm{H} 9 \mathrm{c} 2$ cells from LPS-induced apoptosis.

LPS is a potent pro-inflammatory cytokine stimulator in cardiomyocytes. A large body of evidence suggests that NF- $\mathrm{B}$ activation, mediated by pro-inflammatory cytokines such as TNF- $\alpha$ or IL-1, serves an important role in the LPS-induced apoptosis of cardiomyocytes (19). A previous report indicated that PPAR $\delta$ regulated inflammation via $N F-\kappa B$ signaling in sepsis (20). However, whether activation of PPAR $\delta$ may inhibit

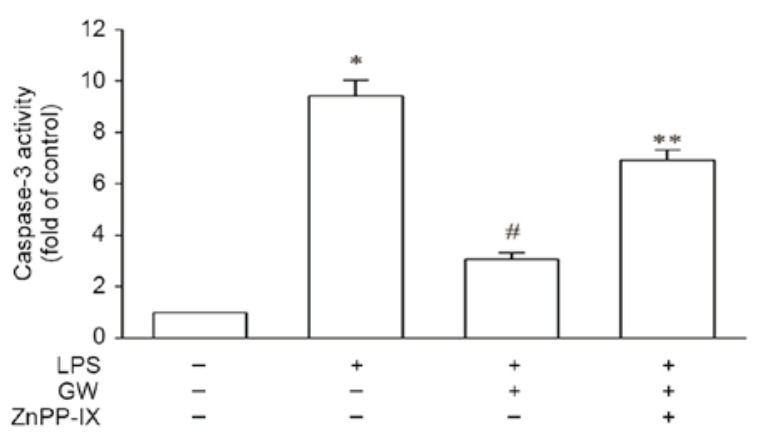

Figure 7. HO-1 mediates the protection of GW from LPS-induced cell apoptosis. Cells were pretreated with $100 \mathrm{nM}$ of $\mathrm{GW}$ for $24 \mathrm{~h}$ with or without $10 \mu \mathrm{mol} / 1$ of $\mathrm{ZnPP}-\mathrm{IX}$, which was added $1 \mathrm{~h}$ before $\mathrm{GW}$, following which the cells were incubated for $24 \mathrm{~h}$ with $1 \mu \mathrm{g} / \mathrm{ml}$ LPS. Data are presented as mean \pm standard deviation $(n=3)$. ${ }^{*} \mathrm{P}<0.05$ vs. control; ${ }^{\#} \mathrm{P}<0.05$ vs. $\mathrm{LPS}$; ${ }^{* *} \mathrm{P}<0.05$ vs. LPS + GW. GW, GW501516; HO-1, heme oxygenase-1; LPS, lipopolysaccharide; Znpp-IX, zincprotoporphyrin-IX.

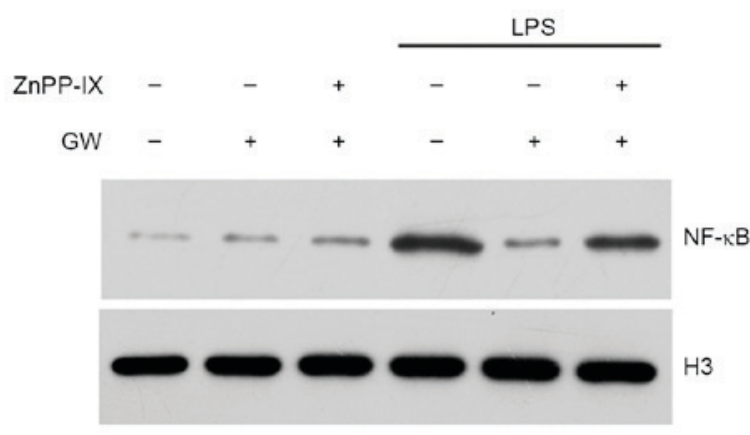

Figure 8. HO-1 mediates the inhibitory effect of GW on NF- $\kappa \mathrm{B}$ activation in LPS-stimulated cells. Cells were pretreated with GW, ZnPP-IX, or LPS as indicated and $\mathrm{NF}-\kappa \mathrm{B}$ was determined by western blot analysis. Cells were incubated for $24 \mathrm{~h}$ in the absence or presence of $10 \mu \mathrm{mol} / 1$ of $\mathrm{ZnPP}-\mathrm{IX}$, which was added $1 \mathrm{~h}$ before GW. Following pretreatment, cells were incubated for another $24 \mathrm{~h}$ with or without LPS. GW, GW501516; HO-1, heme oxygenase-1; LPS, lipopolysaccharide; NF- $\kappa \mathrm{B}$, nuclear factor- $\kappa \mathrm{B}$; ZnPP-IX, zinc protoporphyrin-IX; H3, histone 3.

apoptosis in LPS-stimulated $\mathrm{H} 9 \mathrm{c} 2$ cells via $\mathrm{NF}-\kappa \mathrm{B}$ signaling is still unknown.

$\mathrm{NF}-\kappa \mathrm{B}$ is a nuclear transcription factor that regulates expression of a number of genes that are critical for the regulation of tumorigenesis, inflammation and apoptosis. NF- $\kappa \mathrm{B}$ is activated by a variety of stimuli that include ischemia, cytokines, hypoxia, free radicals and LPS. In the inactive state, $\mathrm{NF}-\kappa \mathrm{B}$ is retained in the cytosol through complexation with inhibitor of NF- $\mathrm{NB}(\mathrm{I} \kappa \mathrm{B})$ proteins. Upon LPS-induced phosphorylation, I $\kappa \mathrm{B} \alpha$ is degraded, and $\mathrm{NF}-\kappa \mathrm{B}$ is released from the cytosolic complex with $\mathrm{I} \kappa \mathrm{B}$ proteins and translocates to the nucleus, where it promotes the transcription of both pro- and anti-apoptotic proteins (21). The association between cardiac $\mathrm{NF}-\kappa \mathrm{B}$ activity and apoptosis remains unclear; in certain cellular systems, it has been proven to be detrimental, and in others, protective (22). It has been suggested that the inhibition of NF- $\kappa \mathrm{B}$ activation in $\mathrm{H} 9 \mathrm{c} 2$ cells may be useful in the prevention of apoptosis induced by LPS (15). In the present study, it was demonstrated that pretreatment with GW inhibited the activation of NF- $\mathrm{NB}$ induced by LPS in a dose-dependent manner. These results suggest that GW prevents LPS-induced apoptosis through inhibition of $\mathrm{NF}-\kappa \mathrm{B}$ activation. 
Pharmacological and genetic induction of HO-1 has been demonstrated to exert an anti-apoptotic effect in various cardiovascular diseases $(23,24)$. A previous study demonstrated that HO-1 was upregulated in endothelial cells and vascular smooth muscle cells by GW in vitro (25), and to the best of our knowledge the present study demonstrates for the first time that $\mathrm{GW}$ induces $\mathrm{HO}-1$ protein expression in a dose-dependent manner in $\mathrm{H} 9 \mathrm{c} 2$ cells. In addition, pretreatment with GW significantly inhibited the LPS-induced activation of caspase-3. This effect was demonstrated to be partly attributed to the induction of HO-1, as the inhibitor of HO-1 (ZnPPIX) markedly reversed the protective effect afforded by GW. These results suggest that the induction of HO-1 may serve a marked role in mediating the anti-apoptotic effect of GW in LPS-stimulated H9c2 cells. Additionally, it was identified in this study that ZnPP-IX co-incubation reversed the inhibitory effect of GW on LPS-induced NF- $\mathrm{KB}$ nuclear translocation, which suggests that HO-1 may mediate the inhibitory effect of GW on NF- $\kappa B$ activation in LPS-stimulated H9c2 cells. Therefore, it was concluded that PPAR $\delta$ activation protects H9c2 cells from LPS-induced apoptosis probably through the HO-1 mediated suppression of NF- $\kappa B$ activation. These results are in agreement with previous reports demonstrating that HO-1 activation attenuates the apoptosis of cardiomyocytes by inhibiting NF- $\mathrm{kB}$ activity (24).

A previous study demonstrated that $\mathrm{CO}$, a product of heme metabolism by HO-1, exhibited a potent anti-apoptotic effect in LPS-stimulated endothelial cells (26); however, whether $\mathrm{CO}$ is involved in the cytoprotection afforded by GW remains unknown. Therefore, experiments aimed at broadening understanding of the more detailed mechanisms will be the subject of future studies.

In conclusion, the present study demonstrates that GW protects $\mathrm{H} 9 \mathrm{c} 2$ cardiomyoblasts against LPS-induced apoptosis. The protective effect of $\mathrm{GW}$ was demonstrated to be associated with the HO-1 mediated suppression of NF- $\mathrm{KB}$ activation. The results suggest that PPAR $\delta$ is a promising therapeutic target for the treatment of sepsis-associated cardiac dysfunction.

\section{References}

1. Czaja AS, Zimmerman JJ and Nathens AB: Readmission and late mortality after pediatric severe sepsis. Pediatrics 123: 849-857, 2009.

2. Watson RS, Carcillo JA, Linde-Zwirble WT, Clermont G, Lidicker J and Angus DC: The epidemiology of severe sepsis in children in the United States. Am J Respir Crit Care Med 167: 695-701, 2003.

3. Maeder M, Fehr T, Rickli H and Ammann P: Sepsis-associated myocardial dysfunction: Diagnostic and prognostic impact of cardiac troponins and natriuretic peptides. Chest 129: 1349-1366, 2006.

4. Ayala A, Perl M, Venet F, Lomas-Neira J, Swan R and Chung CS: Apoptosis in sepsis: Mechanisms, clinical impact and potential therapeutic targets. Curr Pharm Des 14: 1853-1859, 2008.

5. Ehrenborg E and Krook A: Regulation of skeletal muscle physiology and metabolism by peroxisome proliferator-activated receptor delta. Pharmacol Rev 61: 373-393, 2009.

6. Barish GD, Narkar VA and Evans RM: PPAR delta: A dagger in the heart of the metabolic syndrome. J Clin Invest 116: 590-597, 2006.

7. Li AC, Binder CJ, Gutierrez A, Brown KK, Plotkin CR, Pattison JW, Valledor AF, Davis RA, Willson TM, Witztum JL, et al: Differential inhibition of macrophage foam-cell formation and atherosclerosis in mice by PPARalpha, beta/delta, and gamma. J Clin Invest 114: 1564-1576, 2004.
8. Liou JY, Lee S, Ghelani D, Matijevic-Aleksic N and Wu KK: Protection of endothelial survival by peroxisome proliferator-activated receptor-delta mediated 14-3-3 upregulation. Arterioscler Thromb Vasc Biol 26: 1481-1487, 2006.

9. Piqueras L, Reynolds AR, Hodivala-Dilke KM, Alfranca A, Redondo JM, Hatae T, Tanabe T, Warner TD and Bishop-Bailey D: Activation of PPARbeta/delta induces endothelial cell proliferation and angiogenesis. Arterioscler Thromb Vasc Biol 27: 63-69, 2007.

10. Pesant M, Sueur S, Dutartre P, Tallandier M, Grimaldi PA, Rochette L and Connat JL: Peroxisome proliferator-activated receptor delta (PPARdelta) activation protects H9c2 cardiomyoblasts from oxidative stress-induced apoptosis. Cardiovasc Res 69: 440-449, 2006.

11. Carlson D, Maass DL, White DJ, Tan J and Horton JW: Antioxidant vitamin therapy alters sepsis-related apoptotic myocardial activity and inflammatory responses. Am J Physiol Heart Circ Physiol 291: H2779-H2789, 2006.

12. Otterbein LE and Choi AM: Heme oxygenase: Colors of defense against cellular stress. Am J Physiol Lung Cell Mol Physiol 279: L1029-L1037, 2000.

13. Ali F, Ali NS, Bauer A, Boyle JJ, Hamdulay SS, Haskard DO, Randi AM and Mason JC: PPARdelta and PGClalpha act cooperatively to induce haem oxygenase-1 and enhance vascular endothelial cell resistance to stress. Cardiovasc Res 85: 701-710, 2010.

14. Zabalgoitia M, Colston JT, Reddy SV, Holt JW, Regan RF, Stec DE, Rimoldi JM, Valente AJ and Chandrasekar B: Carbon monoxide donors or heme oxygenase-1 (HO-1) overexpression blocks interleukin-18-mediated NF-kappaB-PTEN-dependent human cardiac endothelial cell death. Free Radic Biol Med 44: 284-298, 2008

15. Tien YC, Lin JY, Lai CH, Kuo CH, Lin WY, Tsai CH, Tsai FJ, Cheng YC, Peng WH and Huang CY: Carthamus tinctorius L. Prevents LPS-induced TNFalpha signaling activation and cell apoptosis through JNK1/2-NFkappaB pathway inhibition in H9c2 cardiomyoblast cells. J Ethnopharmacol 130: 505-513, 2010.

16. Jiang B, Liang P, Zhang B, Song J, Huang X and Xiao X: Role of PPAR-beta in hydrogen peroxide-induced apoptosis in human umbilical vein endothelial cells. Atherosclerosis 204: 353-358, 2009.

17. Cryns V and Yuan J: Proteases to die for. Genes Dev 12: 1551-1570, 1998.

18. Oltvai ZN, Milliman CL and Korsmeyer SJ: Bcl-2 heterodimerizes in vivo with a conserved homolog, Bax, that accelerates programmed cell death. Cell 74: 609-619, 1993.

19. Wang X, Zingarelli B, O'Connor M, Zhang P, Adeyemo A, Kranias EG, Wang Y and Fan GC: Overexpression of Hsp20 prevents endotoxin-induced myocardial dysfunction and apoptosis via inhibition of NF-kappaB activation. J Mol Cell Cardiol 47: 382-390, 2009.

20. Zingarelli B, Piraino G, Hake PW, O'Connor M, Denenberg A, Fan $\mathrm{H}$ and Cook JA: Peroxisome proliferator-activated receptor \{delta\} regulates inflammation via NF- $\{$ kappa\}B signaling in polymicrobial sepsis. Am J Pathol 177: 1834-1847, 2010.

21. Abdulkhalek S, Guo M, Amith SR, Jayanth P and Szewczuk MR: G-protein coupled receptor agonists mediate Neu1 sialidase and matrix metalloproteinase- 9 cross-talk to induce transactivation of TOLL-like receptors and cellular signaling. Cell Signal 24: 2035-2042, 2012.

22. Delhalle S, Blasius R, Dicato M and Diederich M: A beginner's guide to NF-kappaB signaling pathways. Ann N Y Acad Sci 1030: 1-13, 2004.

23. Wang G, Hamid T, Keith RJ, Zhou G, Partridge CR, Xiang X, Kingery JR, Lewis RK, Li Q, Rokosh DG, et al: Cardioprotective and antiapoptotic effects of heme oxygenase-1 in the failing heart. Circulation 121: 1912-1925, 2010.

24. Yeh CH, Chen TP, Wang YC, Lin YM and Lin PJ: HO-1 activation can attenuate cardiomyocytic apoptosis via inhibition of NF-kappaB and AP-1 translocation following cardiac global ischemia and reperfusion. J Surg Res 155: 147-156, 2009.

25. Kim HJ, Ham SA, Paek KS, Hwang JS, Jung SY, Kim MY, Jin H, Kang ES, Woo IS, Kim HJ, et al: Transcriptional up-regulation of antioxidant genes by PPARd inhibits angiotensin II-induced premature senescence in vascular smooth muscle cells. Biochem Biophys Res Commun 406: 564-569, 2011.

26. Bernardini C, Zannoni A, Bacci ML and Forni M: Protective effect of carbon monoxide pre-conditioning on LPS-induced endothelial cell stress. Cell Stress Chaperones 15: 219-224, 2010. 